\title{
Pengaruh Perubahan Parameter Fisik-Kimia terhadap Aktivitas Mikroorganisme selama Proses Pengomposan Sampah Organik Kantin \\ Cut Keumala Banaget ${ }^{1}$, Gabriel S. Boedi Andari Kristanto ${ }^{2}$, Irma Gusniani D. ${ }^{3}$ \\ ${ }^{1}$ Institut Teknologi Kalimantan, Balikpapan, Indonesia. Email: c.keumala@itk.ac.id \\ 2,3 Universitas Indonesia, Depok, Indonesia. Email: andari@ui.ac.id, irma@ui.ac.id
}

\begin{abstract}
Abstrak:
Pengolahan sampah sisa makanan perlu menjadi prioritas karena jumlahnya yang besar serta sifatnya yang mudah membusuk dan memicu kehadiran hewan pembawa penyakit seperti tikus.Salah satu teknik pengolahannya adalah pengomposan, yaitu proses degradasi sampah organik oleh mikroorganisme menjadi material sejenis humus yang dapat dimanfaatkan. Tujuan penelitian ini adalah untuk menganalisis faktor-faktor (meliputi parameter fisik-kimia) yang mempengaruhi proses pengomposan, serta menganalisis hubungan dan pengaruh faktor tersebut terhadap aktivitas mikroorganisme selama proses pengomposan berlangsung. Analisis statistik dalam penelitian ini meliputi analisis faktor, korelasi, dan multivariabel. Berdasarkan analisis faktor yang dilakukan, terbentuk 2 faktor baru yang mempengaruhi proses pengomposan, yaitu faktor 1 dinamakan parameter yang menunjukkan hasil dari proses pengomposan, terdiri dari konduktivitas, salinitas, dan kadar air; dan faktor 2 dinamakan parameter yang mendukung proses pengomposan, terdiri dari rasio $C / N$, kadar karbon, $p H$, dan kadar nitrogen. Hasil analisis korelasi menunjukkan kadar air, rasio $C / N$, kadar karbon, pH, kadar nitrogen memiliki pengaruh terhadap aktivitas mikroorganisme. Berdasarkan analisis multivariabel, komposter 2 diperkirakan memiliki model regresi pengaruh faktor pengomposan terhadap aktivitas mikroorganisme yang terbaik. Sedangkan dilihat dari penurunan kadar karbonnya, komposter 1 memiliki konstanta laju pengomposan dan laju dekomposisi terbesar dibandingkan dua komposter lainnya, yaitu sebesar 0,0006 dan 0,0224\%/hari.
\end{abstract}

Kata kunci: pengomposan; sampah kantin; parameter fisik-kimia; aktivitas mikroorganisme; laju dekomposisi

\subsection{PENDAHULUAN}

Sampah organik merupakan komponen sampah yang dapat terdegradasi (membusuk) oleh aktivitas mikroorganisme, meliputi sisa makanan, dedaunan, kertas, dan kayu. Di Indonesia, 58\% komponen sampah dari total timbulan sampah yang dihasilkan merupakan sampah organik atau berjumlah 22,4 juta ton/tahun (Data Statistik Persampahan Domestik Indonesia, 2008). Pengolahan sampah organik, terutama sampah sisa makanan, perlu menjadi prioritas, selain karena besarnya persentase sampah organik yang dihasilkan, sifat sampah sisa makanan yang mudah membusuk, menimbulkan bau tidak sedap, dan dapat memicu kehadiran hewan pembawa penyakit, seperti kecoa dan tikus. Salah satu teknik pengolahan sampah yang dapat dilakukan untuk menangani sampah sisa makanan adalah pengomposan. Pengomposan diperkirakan dapat menjadi salah satu cara terbaik untuk mengolah sampah sisa makanan karena dapat mengubah sampah organik menjadi bentuk yang stabil dan bisa digunakan kembali sebagai pupuk organik.

Pengomposan merupakan proses degradasi zat organik yang kompleks dan heterogen oleh berbagai mikroorganisme (Simujide et al, 2013). Menurut Raut et al (2008), keseluruhan efisiensi penguraian sampah organik bergantung pada mikroorganisme dan aktivitasnya. Dalam proses degradasi zat organik, mikroorganisme menghasilkan enzim yang berfungsi sebagai katalis atau untuk mempercepat proses degradasi tersebut. Enzim penting yang terlibat dalam proses pengomposan antara lain adalah selulase yang mendepolimerisasi selulosa dan protease yang mendegradasi protein. Karakterisasi dan kuantifikasi aktivitas enzim selama pengomposan dapat menunjukkan dinamika proses pengomposan dalam hal dekomposisi zat organik dan transformasi nitrogen, dan dapat memberikan informasi mengenai kematangan produk kompos (Tiquia, 2002). 
Tujuan dilaksanakannya penelitian ini adalah menganalisis hubungan dan pengaruh faktor-faktor pengomposan terhadap aktivitas mikroorganisme selama proses pengomposan berlangsung, serta menganalisis proses dekomposisi zat organik yang terjadi selama proses pengomposan berlangsung.

\subsection{METODE PENELITIAN}

Metode pengomposan yang dilakukan adalah metode in-vessel dengan menggunakan tong volume 60 $\mathrm{L}$ dan dilengkapi lubang untuk keperluan aerasi. Dalam penelitian ini, sampah organik yang menjadi bahan baku utama kompos adalah sampah sisa makanan dari kantin dengan bulking agent berupa sampah daun kering. Pengomposan dilakukan selama 60 hari dengan 3 variasi komposisi feedstock: komposter 1, perbandingan 3:1 (15 kg sampah makanan dan $5 \mathrm{~kg}$ sampah halaman); komposter 2, perbandingan 1:1 (10 kg sampah makanan dan $10 \mathrm{~kg}$ sampah halaman); dan komposter 3, perbandingan 1:3 (5 kg sampah makanan dan $15 \mathrm{~kg}$ sampah halaman).

Variabel yang diamati adalah parameter fisik-kimia proses pengomposan meliputi temperatur, $\mathrm{pH}$, konduktivitas, salinitas, kadar air, kadar karbon, kadar nitrogen, dan rasio karbon-nitrogen, serta aktivitas mikroorganisme yang meliputi populasi mikroorganisme bakteri proteolitik dan selulolitik, serta aktivitas enzim protease dan selulase. Data parameter fisik-kimia dan aktivitas mikroorganisme dianalisis secara deskriptif untuk menjelaskan perubahan parameter yang terjadi selama proses pengomposan, lalu dilakukan analisis faktor yang mempengaruhi proses pengomposan. Selanjutnya dilakukan analisis korelasi dan multivariabel untuk menjelaskan hubungan dan pengaruh faktor-faktor hasil analisis terhadap aktivitas mikroorganisme.

\subsection{HASIL PENELITIAN \& PEMBAHASAN}

\subsection{Analisis Perubahan Parameter Fisik-Kimia dan Aktivitas Mikroorganisme selama Proses Pengomposan Berlangsung}

Fase termofilik pada ketiga komposter terjadi dalam rentang temperatur $45-50^{\circ} \mathrm{C}$ dalam waktu yang relatif singkat, yaitu pada 5 hari pertama pengomposan. Bahkan komposter 1 tidak mengalami fase termofilik karena temperatur tertinggi kompos hanya sebesar $43,5^{\circ} \mathrm{C}$. Temperatur kompos yang relatif rendah pada fase termofilik dapat disebabkan oleh volume sampah yang dikomposkan kecil, yaitu kurang dari $60 \mathrm{~L}$. Dalam rentang temperatur $30-45^{\circ} \mathrm{C}$, proses dekomposisi zat organik tetap terjadi karena temperatur tersebut masih memungkinkan untuk pertumbuhan bakteri tetapi untuk mematikan patogen tidak dapat dipastikan karena proses penghilangan patogen berlangsung pada suhu di atas $55^{\circ} \mathrm{C}$ (Colón et al, 2010).

Kompos pada ketiga komposter memiliki $\mathrm{pH}$ awal yang cukup asam, yaitu di bawah 6 . Nilai pH yang rendah pada awal proses pengomposan dapat disebabkan oleh pembentukan asam organik dari proses dekomposisi zat organik atau glukosa yang mudah terdegradai oleh mikroorganisme. Selanjutnya nilai pH untuk ketiga komposter meningkat menjadi diatas 7. Menurut Jiang et al (2011), kenaikan pH tersebut merupakan hasil degradasi protein yang menggunakan asam organik dan asam menengah yang dihasilkan dari degradasi glukosa yang tidak cukup untuk menetralkan zat alkali.

Nilai konduktivitas komposter 1 berada dalam rentang 4,33 sampai $6,98 \mathrm{mS} / \mathrm{cm}$; komposter 2 memiliki nilai konduktivitas dalam rentang 3,85 sampai 7,05 mS/cm; dan komposter 3 memiliki nilai konduktivitas dalam rentang 2,83 sampai $5,83 \mathrm{mS} / \mathrm{cm}$. Menurut Liu et al (2011), nilai konduktivitas terbesar diperoleh pada akhir proses pengomposan yang dapat disebabkan oleh pelepasan ion mineral berbeda, seperti fosfat, ammonia, dan potassium. Sedangkan penurunan kadar konduktivitas selama proses pengomposan dapat disebabkan oleh larutnya garam oleh kadar air kompos (Getahun et al, 2012). Nilai salinitas kompos pada ketiga komposter menunjukkan perubahan yang fluktuatif yang sama dengan konduktivitas. 

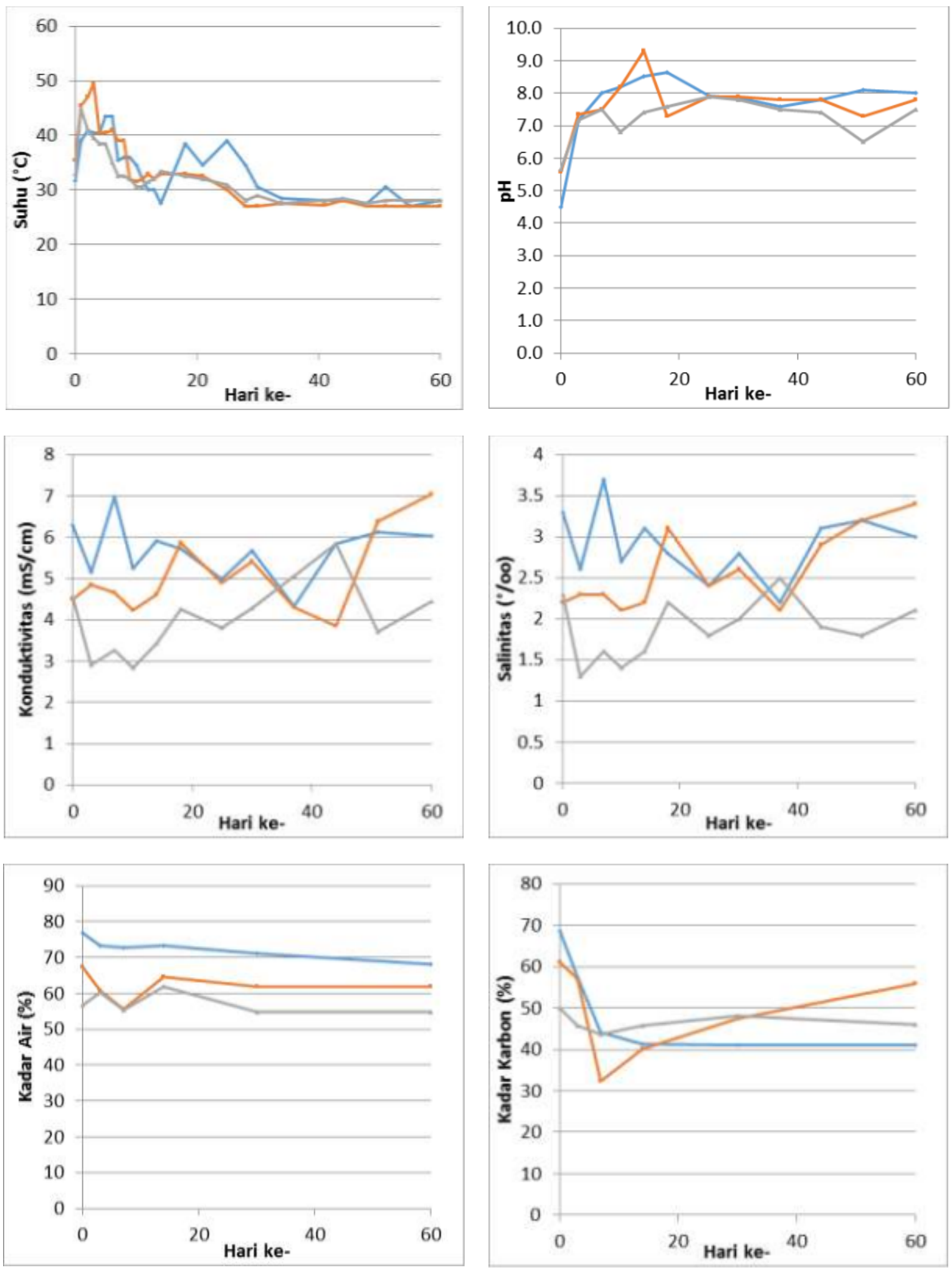

Komposter 1

Komposter 1

Komposter 1

Gambar 1. Perubahan Parameter Fisik-Kimia selama Proses Pengomposan 


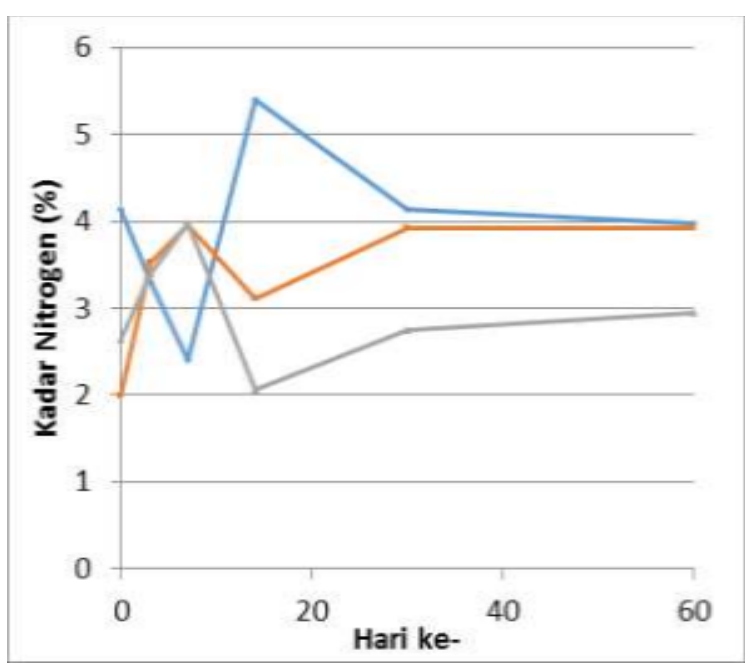

Komposter 1

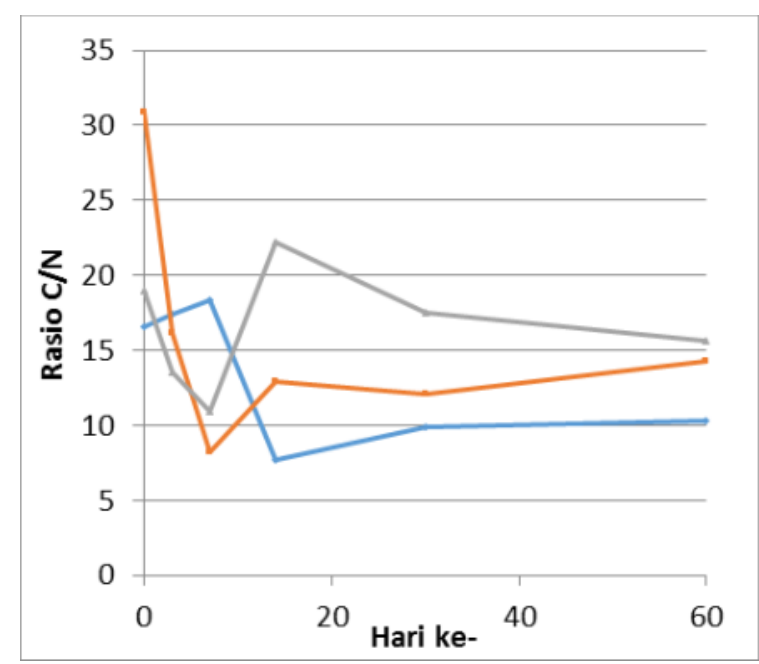

Komposter 1

\section{Gambar 1. (Lanjutan) Perubahan Parameter Fisik-Kimia selama Proses Pengomposan}

Ketiga komposter mengalami penurunan kadar karbon, yaitu dari 68,68 menjadi 44,03\% (komposter 1), dari 61,18 menjadi 32,44\% (komposter 2), dan dari 50,05 menjadi 43,70\% (komposter 3). Hilangnya karbon terjadi karena pembentukan karbon dioksida dari massa kompos sebagai produk akhir metabolisme. Selama proses pengomposan, karbon dioksida diemisikan dari massa kompos sebagai produk akhir metabolisme. Sehingga kandungan karbon total dalam massa kompos menurun selama proses berlangsung (Vuorinen \& Saharinen, 1997).

Pada minggu pertama pengomposan, kadar nitrogen pada komposter 1 mengalami penurunan dari 4,13 menjadi 2,40\%. Sedangkan kadar nitrogen kompos pada komposter 2 dan 3 mengalami peningkatan, yaitu dari 1,98 menjadi 3,95\% (komposter 2) dan dari 2,63 menjadi 3,98\% (komposter 3). Penurunan kadar nitrogen terjadi karena pembentukan ammonia dan peningkatan yang terjadi disebabkan oleh degradasi campuran karbon organik yang menyebabkan hilangnya karbon selama pengomposan. Sedangkan kenaikan kadar nitrogen terutama disebabkan oleh hilangnya karbon selama pengomposan (Vuorinen \& Saharinen, 1997).

Kompos pada komposter 1 mengalami penurunan rasio karbon-nitrogen dari 16,63 menjadi 10,32. Sedangkan komposter 2 dan 3 mengalami penurunan pada minggu pertama pengomposan, yaitu dari 30,90 menjadi 14,27 (komposter 2) dan dari 19,03 menjadi 15,66 (komposter 3). Penurunan nilai rasio karbon-nitrogen terjadi karena penurunan kadar karbon yang terjadi selama proses pengomposan dan peningkatan kadar nitrogen yang menunjukkan terjadi proses degradasi protein dalam sampah organik menjadi asam amino.

Pada awal proses pengomposan, komposter 1 dan 3 memiliki jumlah bakteri penghasil enzim protease yang paling tinggi dibandingkan jumlah bakteri pada tahap selanjutnya, yaitu mencapai $70 \times 10^{-8}$ CFU/Plate untuk komposter 1 dan $202 \times 10^{8}$ CFU/Plate untuk komposter 3. Selama pengomposan, jumlah bakteri proteolitik pada ketiga komposter mengalami perubahan yang relatif sama, yaitu jumlah bakteri mengalami penurunan pada hari ke-3 dan kemudian kembali mengalami peningkatan sebelum akhirnya turun kembali pada akhir proses pengomposan.

Sedangkan, jumlah bakteri selulolitik pada komposter 1 pada awal proses pengomposan nilainya lebih besar dari jumlah bakteri pada dua komposter lainnya. Hal tersebut menunjukkan proses degradasi 
selulosa pada komposter 1 terjadi pada awal pengomposan. Sedangkan untuk komposter 2 dan 3, proses degradasi selulosa masih terus berlangsung hingga akhir pengomposan. Hal tersebut dapat terjadi karena pada kedua komposter ini proses degradasi selulosa masih berlangsung hingga akhir proses pengomposan, mengingat selulosa merupakan zat organik yang cukup sulit untuk diuraikan.
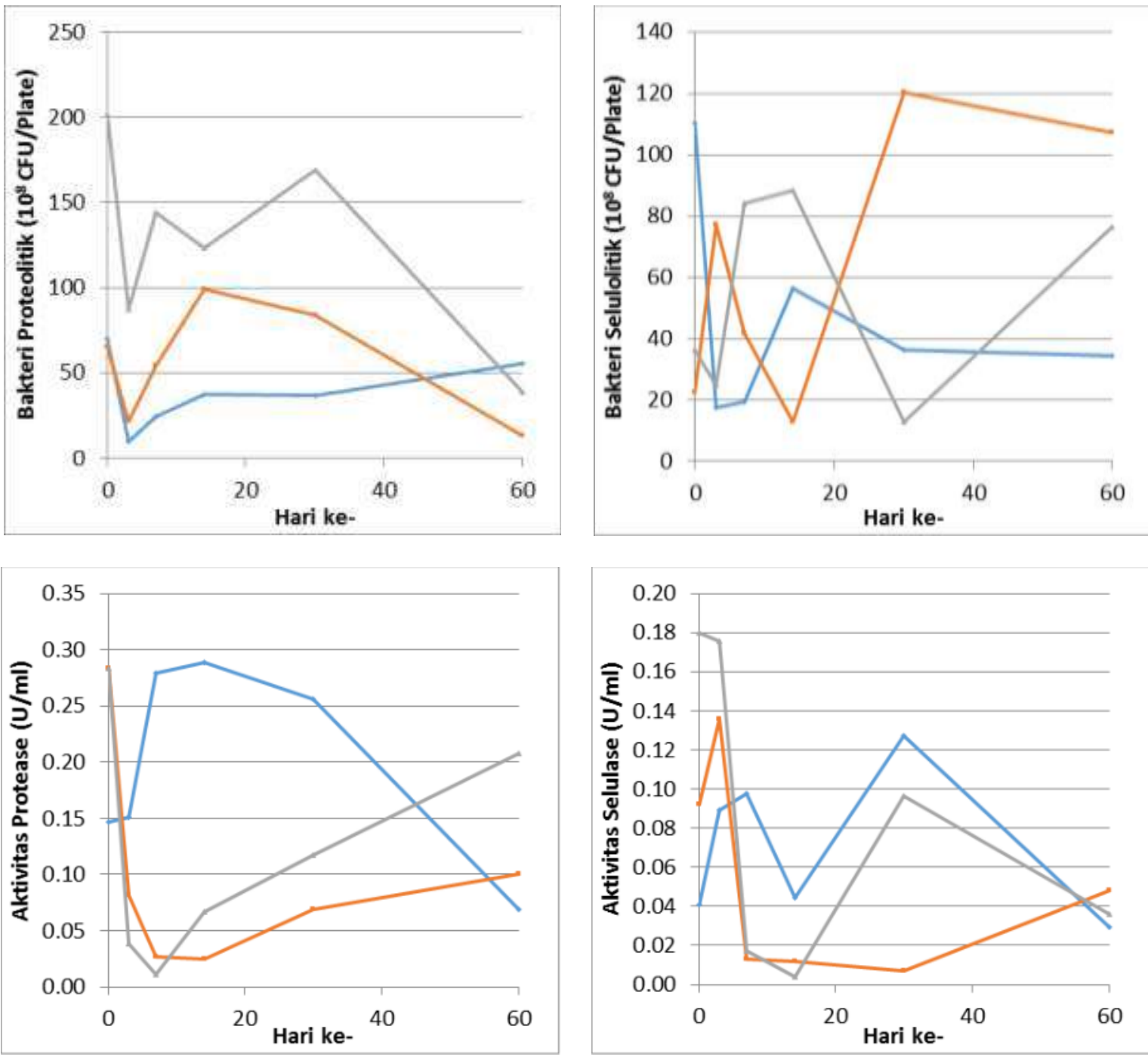

Komposter 1
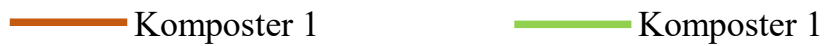

Gambar 2. Aktivitas Mikroorganisme selama Proses Pengomposan

Pada awal proses pengomposan, aktivitas enzim protease komposter 2 dan 3 memiliki nilai terbesar, yaitu mencapai $0,284 \mathrm{U} / \mathrm{ml}$. Setelah itu, aktivitas enzim menurun dan mengalami peningkatan setelah hari ke-14. Hal tersebut dapat terjadi karena ada protein yang belum terdegradasi pada tahap awal pengomposan sehingga aktivitas enzim kembali meningkat. Berbeda dengan komposter lainnya, aktivitas enzim protease pada komposter 1 meningkat hingga hari ke-14. Sedangkan aktivitas enzim selulase pada ketiga komposter memiliki nilai yang fluktuatif. Pada awal proses pengomposan, aktivitas enzim selulase pada komposter 1 memiliki nilai terkecil diantara dua komposter lainnya, yaitu mencapai $0,041 \mathrm{U} / \mathrm{ml}$. Sedangkan aktivitas enzim selulase pada komposter 2 dan 3 memiliki nilai yang cukup tinggi, yaitu sebesar 0,092 dan $0,180 \mathrm{U} / \mathrm{ml}$, akan tetapi aktivitasnya menurun pada tahap aktif pengomposan. 


\subsection{Analisis Faktor yang Mempengaruhi Aktivitas Mikroorganisme}

Analisis faktor digunakan untuk menganalisis struktur saling hubungan (korelasi) antar sejumlah besar variabel dengan cara mendefinisikan satu set kesamaan variabel atau dimensi dan sering disebut dengan faktor. Nilai KMO yang didapat dari perhitungan dengan program SPSS menunjukkan hasil sebesar 0,567 yang memenuhi syarat (nilai diatas 0,50). Selain itu hasil Barlett's Test memiliki signifikan pada 0,000 yang artinya signifikan kurang dari 0,05 sehingga analisis faktor dapat dilakukan. Dari 8 parameter fisik-kimia yang dianalisis, yaitu temperatur, $\mathrm{pH}$, konduktivitas, salinitas, kadar air, kadar karbon, nitrogen, dan rasio $\mathrm{C} / \mathrm{N}$, didapatkan dua faktor hasil ekstraksi SPSS, yaitu faktor dengan nilai eigen lebih besar dari 1. Faktor 1 memiliki persentase varians sebesar 37,505 atau berarti mampu menjelaskan 37,5\% variasi dan faktor 2 mampu menjelaskan 31,9\% variasi.

Parameter fisik-kimia kemudian dikelompokan dalam masing-masing faktor berdasarkan nilai komponen indikator kedua faktor yang lebih dari 0,50. Indikator salinitas, konduktivitas, kadar nitrogen, kelembapan, dan rasio $\mathrm{C} / \mathrm{N}$ mengelompok pada faktor 1; dan indikator kelembapan, kadar karbon, $\mathrm{pH}$, dan rasio $\mathrm{C} / \mathrm{N}$ mengelompok pada faktor 2. Hasil tersebut belum dapat disimpulkan karena indikator kelembapan dan rasio $\mathrm{C} / \mathrm{N}$ berada pada kedua faktor sehingga pembagian faktor menjadi tidak jelas dan harus dilakukan rotasi faktor (factor rotation). Hasil rotasi faktor menunjukkan pengelompokan faktor yang baru, yaitu faktor 1 yang terdiri dari indikator salinitas, konduktivitas, dan kelembapan yang selanjutnya dinamakan parameter yang menunjukkan hasil dari proses dekomposisi oleh aktivitas mikroorganisme; dan faktor 2 yang terdiri dari indikator rasio $\mathrm{C} / \mathrm{N}$, kadar karbon, $\mathrm{pH}$, dan kadar nitrogen yang dinamakan parameter yang mendukung aktivitas mikroorganisme selama proses pengomposan berlangsung.

\subsection{Analisis Pengaruh Faktor 1 terhadap Aktivitas Mikroorganisme}

Tabel 1 menunjukkan koefisien korelasi faktor 2 dan aktivitas mikroorganisme.

Tabel 1. Koefisien Korelasi antara Faktor 1 dan Aktivitas Mikroorganisme

\begin{tabular}{|c|c|c|c|c|c|c|c|}
\hline & Konduktivitas & Salinitas & Kadar air & Proteolitik & Selulolitik & Protease & Selulase \\
\hline \multicolumn{8}{|c|}{ Komposter 1} \\
\hline Konduktivitas & 1 & & & & & & \\
\hline Salinitas & $0,984^{* *}$ & 1 & & & & & \\
\hline Kadar air & 0,134 & 0,276 & 1 & & & & \\
\hline Proteolitik & 0,302 & 0,255 & 0,110 & 1 & & & \\
\hline Selulolitik & 0,176 & 0,227 & 0,650 & $0,809^{*}$ & 1 & & \\
\hline Protease & 0,270 & 0,332 & 0,252 & $-0,402$ & $-0,141$ & 1 & \\
\hline Selulase & $-0,127$ & $-0,153$ & $-0,048$ & $-0,633$ & $-0,510$ & 0,528 & 1 \\
\hline \multicolumn{8}{|c|}{ Komposter 2} \\
\hline Konduktivitas & 1 & & & & & & \\
\hline Salinitas & $0,998^{* *}$ & 1 & & & & & \\
\hline Kadar air & $-0,072$ & $-0,094$ & 1 & & & & \\
\hline Proteolitik & $-0,648$ & $-0,640$ & 0,319 & 1 & & & \\
\hline Selulolitik & $0,791^{*}$ & $0,777^{*}$ & $-0,242$ & $-0,936^{* *}$ & 1 & & \\
\hline Protease & $-0,220$ & $-0,204$ & 0,665 & 0,082 & $-0,253$ & 1 & \\
\hline Selulase & $-0,395$ & $-0,417$ & 0,242 & $-0,082$ & $-0,199$ & 0,531 & 1 \\
\hline \multicolumn{8}{|c|}{ Komposter 3} \\
\hline Konduktivitas & 1 & & & & & & \\
\hline Salinitas & $0,986^{* *}$ & 1 & & & & & \\
\hline Kadar air & $-0,622$ & $-0,632$ & 1 & & & & \\
\hline Proteolitik & 0,347 & 0,454 & $-0,125$ & 1 & & & \\
\hline Selulolitik & $-0,187$ & $-0,136$ & 0,154 & 0,502 & 1 & & \\
\hline Protease & $0,899^{* *}$ & $0,910^{* *}$ & $-0,381$ & 0,577 & $-0,199$ & 1 & \\
\hline Selulase & 0,120 & 0,131 & 0,031 & $-0,018$ & $-0,822^{*}$ & 0,371 & 1 \\
\hline
\end{tabular}

*. Korelasi signifikan pada 0,$05 ; * *$. Korelasi signifikan pada 0,01 
Kadar air komposter 1 dan 2 memiliki nilai korelasi cukup kuat untuk hubungan kadar air dengan populasi bakteri selulolitik $(r=0,650)$ dan aktivitas enzim protease $(r=0,665)$. Nilai korelasi yang tidak signifikan untuk hubungan kadar air dengan aktivitas mikroorganisme dapat disebabkan karena mikroorganisme dapat berkembang dengan baik jika selama proses pengomposan, kadar air berada dalam rentang $50-80 \%$. Sehingga kenaikan kadar air tidak memiliki pengaruh yang kuat terhadap peningkatan aktivitas mikroorganisme selama kadar air kompos berada dalam rentang optimum.

\subsection{Analisis Pengaruh Faktor 2 terhadap Aktivitas Mikroorganisme}

Pada komposter 2, korelasi antara rasio karbon-nitrogen terhadap aktivitas enzim menunjukkan nilai positif yang sangat kuat untuk aktivitas protease $(\mathrm{r}=0,973 ; \mathrm{p}=0,01)$ dan cukup kuat untuk aktivitas selulase $(r=0,589)$. Pada komposter 3 , rasio karbon-nitrogen dan aktivitas enzim protease memiliki korelasi yang cukup kuat $(\mathrm{r}=0,416)$.

Tabel 2. Koefisien Korelasi antara Faktor 2 dan Aktivitas Mikroorganisme

\begin{tabular}{|c|c|c|c|c|c|c|c|c|}
\hline & $\mathbf{C} / \mathbf{N}$ & C & pH & $\mathbf{N}$ & Prot eolitik & Selulolitik & Protease & Selulase \\
\hline \multicolumn{9}{|c|}{ Komposter 1} \\
\hline $\mathbf{C} / \mathbf{N}$ & 1 & & & & & & & \\
\hline C & 0,637 & 1 & & & & & & \\
\hline pH & $-0,513$ & $-0,935$ & 1 & & & & & \\
\hline $\mathbf{N}$ & $-0,819$ & $-0,124$ & 0,055 & 1 & & & & \\
\hline Proteoliti & $-0,263$ & 0,258 & $-0,537$ & 0,430 & 1 & & & \\
\hline Selulolitik & $-0,030$ & 0,622 & $-0,781$ & 0,481 & $0,809^{*}$ & 1 & & \\
\hline Protease & $-0,135$ & $-0,377$ & 0,398 & 0,075 & $-0,402$ & $-0,141$ & 1 & \\
\hline Selulase & 0,217 & $-0,213$ & $-0,213$ & $-0,452$ & $-0,633$ & $-0,510$ & 0,528 & 1 \\
\hline \multicolumn{9}{|c|}{ Komposter 2} \\
\hline $\mathrm{C} / \mathbf{N}$ & 1 & & & & & & & \\
\hline $\mathbf{C}$ & 0,762 & 1 & & & & & & \\
\hline pH & $-0,754$ & $-0,640$ & 1 & & & & & \\
\hline $\mathbf{N}$ & $-0,906$ & $-0,468$ & 0,501 & 1 & & & & \\
\hline Proteoliti & 0,175 & $-0,384$ & 0,268 & $-0,567$ & 1 & & & \\
\hline Selulolitik & $-0,319$ & 0,273 & $-0,010$ & 0,664 & $-0,936^{* *}$ & 1 & & \\
\hline Protease & $0,973^{* *}$ & 0,707 & $-0,853^{*}$ & $-0,846^{*}$ & 0,082 & $-0,253$ & 1 & \\
\hline Selulase & 0,589 & 0,628 & $-0,520$ & $-0,481$ & $-0,082$ & $-0,199$ & 0,531 & 1 \\
\hline \multicolumn{9}{|c|}{ Komposter 3} \\
\hline $\mathrm{C} / \mathrm{N}$ & 1 & & & & & & & \\
\hline $\mathbf{C}$ & 0,550 & 1 & & & & & & \\
\hline pH & $-0,195$ & $-0,569$ & 1 & & & & & \\
\hline $\mathbf{N}$ & $-0,988^{* *}$ & $-0,546$ & 0,192 & 1 & & & & \\
\hline Prot eoliti & 0,057 & 0,124 & $-0,830^{*}$ & $-0,017$ & 1 & & & \\
\hline Selulolitik & 0,018 & $-0,635$ & 0,22 & 0,012 & 0,502 & 1 & & \\
\hline Protease & 0,416 & $0,799^{*}$ & $-0,847^{*}$ & $-0,441$ & 0,577 & $-0,199$ & 1 & \\
\hline Selulase & $-0,041$ & 0,655 & $-0,476$ & 0,038 & $-0,018$ & $-0,822^{*}$ & 0,371 & 1 \\
\hline
\end{tabular}

*. Korelasi signifikan pada 0,$05 ; * *$. Korelasi signifikan pada 0,01 
Kadar karbon memiliki korelasi positif yang cukup kuat dengan populasi bakteri selulolitik $(r=0,622$ untuk komposter 1) dan dengan aktivitas enzim selulase ( $r=0,628$ untuk komposter 2 dan $r=-0,655$ untuk komposter 3). Hubungan yang relatif kuat tersebut dapat terjadi karena karbon menunjukkan ketersediaan zat organik atau dalam hal ini adalah selulase yang akan diuraikan oleh bakteri selulolitik dan enzim selulase. Semakin tinggi kadar karbon, maka semakin banyak bakteri selulolitik dan enzim selulase yang dibutuhkan untuk menguraikan zat organik dalam kompos tersebut.

Pada komposter 2, kadar nitrogen memiliki nilai korelasi negatif yang cukup kuat untuk populasi bakteri proteolitik $(r=-0,567)$ dan korelasi yang kuat terhadap aktivitas enzim protease $(r=-0,846 ; p=$ $0,005)$. Nilai tersebut memiliki arti bahwa semakin tinggi kadar nitrogen kompos, maka semakin rendah populasi bakteri proteolitik dan aktivitas enzim protease. Hal tersebut dapat terjadi karena kadar nitrogen menunjukkan hasil degradasi protein antara lain berupa asam amino, sehingga peningkatan kadar nitrogen menunjukkan protein yang harus didegradasi oleh bakteri proteolitik semakin sedikit.

\subsection{Analisis Proses Dekomposisi Zat Organik selama Pengomposan}

Selama fase aktif proses pengomposan, kadar karbon dalam material menurun disebabkan oleh dekomposisi zat organik oleh mikroorganisme (Bernal et al, 2009). Gambar 5 menunjukkan penurunan kadar karbon selama proses pengomposan berlangsung.

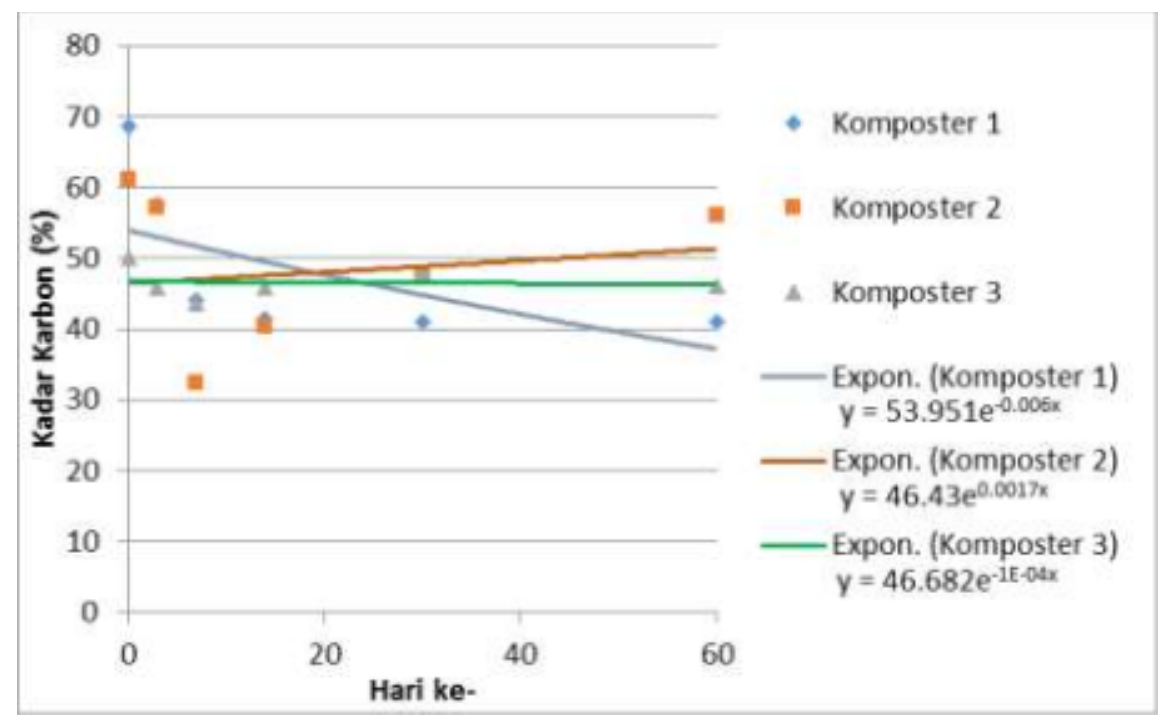

Gambar 3 Grafik Laju Dekomposisi Sampah Organik

Konstanta laju pengomposan komposter 1 memiliki nilai yang paling tinggi, hal tersebut menunjukkan bahwa proses degradasi yang paling aktif terjadi pada komposter tersebut. Sedangkan komposter 2 memiliki konstanta laju pengomposan yang bersifat negatif, hal tersebut disebabkan oleh nilai karbon yang mengalami peningkatan pada hari ke-14 sampai hari ke-60. Walaupun kadar karbon hari ke-60 tetap lebih kecil daripada kadar karbon hari pertama.

Tabel 3. Persamaan dan Konstanta Laju Pengomposan

\begin{tabular}{|c|c|c|}
\hline Komposter & $\begin{array}{r}\text { Persamaan Laju } \\
\text { Dekomp } \\
\text { osisi }\end{array}$ & $\begin{array}{r}\text { Konstanta Laju } \\
\text { Pengo } \\
\text { mposa } \\
\text { n }\end{array}$ \\
\hline 1 & $\mathrm{y}=53,951 \mathrm{e}^{-0,006 \mathrm{x}}$ & 0,006 \\
\hline 2 & $\mathrm{y}=46,43 \mathrm{e}^{0,0017 \mathrm{x}}$ & $-0,0017$ \\
\hline 3 & $\mathrm{y}=46,682 \mathrm{e}^{-1 \mathrm{E}-04 \mathrm{x}}$ & 0,0001 \\
\hline
\end{tabular}


Sedangkan laju dekomposisi zat organik dihitung dengan melihat nilai kadar karbon pada awal dan akhir proses pengomposan.

Tabel 4. Laju Dekomposisi Zat Organik

\begin{tabular}{|c|c|c|c|}
\hline Komposter & $\begin{array}{r}\text { Kadar Karbon } \\
\text { Aw } \\
\text { al } \\
(\%)\end{array}$ & $\begin{array}{r}\text { Kadar Karbon } \\
\mathbf{A} \\
\mathbf{k} \\
\mathbf{h} \\
\text { ir } \\
( \\
\% \\
) \\
\text { ) }\end{array}$ & $\begin{array}{r}\text { Laju Dekomposisi } \\
(\% / \mathbf{h} \\
\text { ari })\end{array}$ \\
\hline 1 & 68,68 & 41,07 & 0,0224 \\
\hline 2 & 61,18 & 55,93 & 0,0031 \\
\hline 3 & 50,05 & 46,03 & 0,0029 \\
\hline
\end{tabular}

Aktivitas mikroorganisme yang tinggi dalam kompos dapat menghasilkan laju dekomposisi yang lebih tinggi (Price et al, 2013). Laju dekomposisi terbesar terlihat pada komposter 1 dengan nilai sebesar 0,0224 . Nilai tersebut menunjukkan bahwa nilai penurunan kadar karbon yang paling besar dan aktivitas mikroorganisme yang paling tinggi diantara komposter lainnya. Tingginya aktivitas mikroorganisme pada komposter 1 dapat disebabkan oleh campuran feedstock yang $75 \%$ terdiri dari sampah makanan yang mengandung nitrogen, yang berfungsi dalam pertumbuhan mikroorganisme.

\subsection{PENUTUP}

Berdasarkan hasil yang didapat dari penelitian dan pembahasan yang telah diuraikan pada bagian sebelumnya, maka dapat disimpulkan beberapa hal, yaitu:

a. Selama proses pengomposan, nilai $\mathrm{pH}$ dan kadar air berada dalam rentang optimum, yaitu 6,5 - 9 dan $55-80 \%$. Temperatur maksimum kompos tertinggi hanya mencapai $50^{\circ} \mathrm{C}$. Nilai karbon dan nitrogen selama proses pengomposan berada dalam rentang pada akhir pengomposan memiliki nilai sebesar $40-55 \%$ dan $2,9-4 \%$. Rasio karbon-nitrogen pada akhir pengomposan $10-20 \%$.

b. Analisis faktor yang mempengaruhi proses pengomposan menghasilkan 2 faktor baru, yaitu faktor 1 dinamakan parameter yang menunjukkan hasil dari proses dekomposisi oleh aktivitas mikroorganisme, terdiri dari konduktivitas, salinitas, dan kadar air; dan faktor 2 dinamakan parameter yang mendukung aktivitas mikroorganisme selama proses pengomposan berlangsung, terdiri dari rasio $\mathrm{C} / \mathrm{N}$, kadar karbon, $\mathrm{pH}$, dan kadar nitrogen.

c. Komposter 3 memiliki model regresi yang paling baik untuk melihat pengaruh faktor 1 terhadap populasi bakteri proteolitik dan aktivitas enzim protease, sedangkan komposter 2 memiliki model regresi yang paling baik untuk pengaruh faktor 1 terhadap populasi bakteri selulolitik dan aktivitas enzim selulase.

d. Komposter 2 memiliki model regresi yang paling baik untuk melihat pengaruh faktor 2 terhadap populasi bakteri proteolitik dan selulolitik, serta untuk melihat pengaruh faktor 2 terhadap aktivitas enzim protease dan selulase.

e. Komposter 1 memiliki konstanta laju pengomposan dan laju dekomposisi terbesar dibandingkan dua komposter lainnya, yaitu sebesar 0,0006 dan 0,0224\%/hari.

\section{DAFTAR REFERENSI}

Bernal, M.P., Alburquerque, J.A., \& Moral, R. (2009). Composting of animal manures and chemical criteria for compost maturity assessment. A review. Bioresource Technology, 100, 5444-5453.

Colón, Joan, Martínez-Blanco, Julia, Gabarrell, Xavier, Artola, Adriana, Sánchez, Antoni, Rieradevall, Joan \& Font, Xavier. (2010). Environmental assessment of home composting. Resources, Conservation and Recycling, 54, 893-904. 
Getahun, T., Nigusie, A., Entele, T., Van Gerven, T., \& Van der Bruggen, B. (2012). Effect of turning frequencies on composting biodegradable municipal solid waste quality. Resources, Conservation and Recycling, 65, 79-84.

Jiang, Tao, Schuchardt, Frank, Li,Guoxue, Guo, Rui \& Zhao, Yuanqiu. (2011). Effect of C/N ratio, aeration rate and moisture content on ammonia and greenhouse gas emission during the composting. Journal of Environmental Sciences, 23 (10), 1754-1760.

Liu, Dongyang, Erriquens, Flora G., \& Gigliotti, Giovanni. (2011). Changes in biochemical and microbiological parameters during the period of rapid composting of dairy manure with rice chaff. Bioresource Technology, 102, 9040-9049.

Simujide, Huasai, Aorigele, Chen, Wang, Chun-Jie, Lina, Ma, \& Manda, Bai. (2013). Microbial activities during mesophilic composting of manure and effect of calcium cyanamide addition. International Biodeterioration \& Biodegradation, 83, 139-144.

Tiquia, Sonia M., Wan, Judy H.C. \& Tam, Nora F.Y. (2002). Dynamics of yard trimmings composting as determined by dehydrogenase activity, ATP content, arginine ammonification, and nitrification potential. Process Biochemistry, 37, 1057- 1065.

Vuorinen, Arja H. \& Saharinen, Maritta H. (1997). Evolution of microbiological and chemical parameters during manure and straw co-composting in a drum composting system. Agriculture, Ecosystems and Environment, 66, 19-29. 